\title{
Public participation in the budgetary process in the Republic of Croatia
}

GORDAN STRUIĆ, Ph.D. candidate* VJEKOSLAV BRATIĆ, Ph.D.*

Review article**

JEL: H61, K10, K40, L38, D72

doi: $10.3326 /$ pse.42.1.4

\footnotetext{
* The authors would like to thank two anonymous referees for useful comments and suggestions. The views expressed here are solely those of the authors.

${ }^{* *}$ Received: September 11, 2017

Accepted: November 7, 2017

Gordan STRUIĆ

Croatian Parliament, Committee on the Constitution, Standing Orders and Political System, Trg. sv. Marka 6, 10000 Zagreb, Croatia

e-mail: gordan.struic@gmail.com

ORCiD: 0000-0001-6528-4436

Vjekoslav BRATIĆ

Institute of Public Finance, Smičiklasova 21, 10000 Zagreb, Croatia

e-mail: vjekoslav.bratic@ijf.hr

ORCiD: 0000-0002-9295-0286
} 
The International Monetary Fund's fourth review of the Fiscal Transparency Code from 2014 sets out the principle of participation according to which the government must provide citizens with a brief, simple and easily understandable overview of the implications of all budgetary measures and with an opportunity to participate in the budgetary decision-making process. The Fiscal Transparency Code must be implemented in Croatia, which is an IMF member state, so this paper uses an interdisciplinary approach to point out the importance and economic effects of public participation in the budgetary process, identify the normative mechanisms of public participation in the budgetary process, and look into what they comprise of and whether they can help in achieving "participation in budgetary decisionmaking", as provided for by point 2.3.3. of the Code in Croatia. It is assumed that the Croatian legal system provides various normative mechanisms of public participation in the budgetary process, which enables the implementation of the participation principle set out in the Code. These mechanisms are, however, not specific to the budgetary process itself, but rather represent general normative mechanisms of public participation, which apply in the legislative process as well.

Keywords: public, participation mechanisms, budgetary process, the Fiscal Transparency Code, Croatia

\section{INTRODUCTION}

Even though the roots of fiscal transparency ${ }^{1}$ stem from texts written in ancient Greece ${ }^{2}$ as early as the $4^{\text {th }}$ and $5^{\text {th }}$ centuries BC, some mediaeval documents found in England and Catalonia, and a number of European constitutions dating from late $18^{\text {th }}$ to mid-19 $9^{\text {th }}$ century (e.g. the French Constitution of 1791 and the Belgian Constitution of 1831$)^{3}$, it was only in the 1990s that this idea was given more attention $^{4}$ and that international requests for fiscal transparency were gradually formulated, eventually leading to a definition of fiscal transparency.

The lack of fiscal transparency has been identified in professional literature as one of the causes of the financial crises of the 1980s and 1990s. The rise in interest in fiscal transparency issues has increased further because of problems in the functioning of the fiscal system, particularly in view of high deficit and public debt

\footnotetext{
${ }^{1}$ Kopits and Craig (1998:1) define fiscal transparency as "openness toward the public at large about government structure and functions, fiscal policy intentions, public sector accounts, and projections", while Petrie (2011:6) adds that fiscal transparency is a blanket term which comprises four main elements (dimensions): public availability of information, clarity of roles, accountability, and participation.

${ }^{2}$ According to Aristotle (1988:178): “(...) In order to avoid peculation of the public money, the transfer of the revenue should be made at a general assembly of the citizens, and duplicates of the accounts deposited with the different brotherhoods, companies, and tribes."

${ }^{3}$ E.g. Title V, Article 3 of the French Constitution of 1791 stipulates the obligation to provide "detailed accounts of the expenditure of ministerial departments". Under Article 116, paragraph 2 of the Belgian Constitution of 1831, "[The] Court [of Audit] is responsible for examining and validating the general administration accounts and the accounts of all accounting officers answerable to the public treasury." This provision is still found in the current Belgian Constitution, adopted in 2014. (For more information, see: Irwin, 2013:10-11 and 26-29.) ${ }^{4}$ According to Philipps and Stewart (2009:801), the reasons of such interest lie in "the neoliberal turn in economic policy, which emphasizes fiscal discipline" and "the movement to reform institutions to promote good governance", to achieve macroeconomic stability and economic growth.
} 
levels in some countries. In order to overcome these problems, it is crucial to implement institutional reforms, improve fiscal transparency and adopt fiscal rules (for more information, see: Drezgić, 2006:25). According to de Renzio and Wehner (2015:4), the "positive view of the potential impact of transparency and participation in fiscal matters", such as effective fiscal management and accountability, reduced corruption, improved allocation of resources, more trust in the government and higher revenues, has "led to a growing set of international standards and norms", i.e. rules.

The IMF's Code of Good Practices on Fiscal Transparency, adopted in April 1998, is the first comprehensive attempt at shaping international standards for IMF members' fiscal policy management (for more information, see: Petrie, 1999:5). Four reviews of the document have been published so far (November 2017): in 1999, 2001, 2007 and 2014. One of the main novelties introduced in the final (fourth) 2014 version, when the document was officially renamed The Fiscal Transparency Code (translated into Croatian by the Institute of Public Finance, 2014; hereinafter: the FT Code) is the so-called principle of public participation (involvement) $)^{5}$ according to which "the government provides citizens with an accessible summary of the implications of budget policies and an opportunity to participate in budget deliberations" (item 2.3.3. of the FT Code).

Soon after it was incorporated into the FT Code, the principle of participation was incorporated in other international documents such as the OECD Recommendation on Budgetary Governance (OECD, 2015) $)^{6}$ and the Principles of Public Participation in Fiscal Policy (GIFT, 2015)7. For instance, according to item 10 of GIFT's High-Level Principles on Fiscal Transparency, Participation and Accountability (GIFT, 2012; hereinafter: High-Level Principles), citizens and all non-state actors should have the right and "effective opportunities to participate directly in public debate and discussion over the design and implementation of fiscal policies". GIFT's High-Level Principles have been endorsed by the United Nations General Assembly's Resolution 67/218 adopted on 21 December 2012, stating in item 2 that member states are encouraged "to intensify efforts to enhance transparency, participation and accountability in fiscal policies, including through the consideration of the principles set out by the [GIFT]" (for more information, see: United Nations, General Assembly, 2012).

Having in mind that the public participation principle, as one dimension of fiscal transparency, is being incorporated in an increasing number of international documents, this paper examines more closely the legal instruments of public participa-

\footnotetext{
${ }^{5}$ The two terms are used interchangeably herein.

${ }^{6}$ See principle no. 5 - "provide for an inclusive, participative and realistic debate on budgetary choices".

${ }^{7}$ See item no. 9 - the principle of complementarity which ensures mechanisms for public participation and to complement citizen engagement, as well as to "increase the effectiveness of existing governance and accountability systems", which stems from item no. 10 of GIFT's High-Level Principles on Fiscal Transparency, Participation and Accountability (GIFT, 2017b). The Principles of Public Participation in Fiscal Policy (GIFT, 2017a) have been translated into Croatian (IPF, 2017a), as have the GIFT's (2017b) High-Level Principles on Fiscal Transparency, Participation and Accountability (IPF, 2017b).
} 
tion $^{8}$ in the budgetary process in the Republic of Croatia. The primary goal of this interdisciplinary approach is to call attention to the significance and the economic effects of public participation in the budgetary process, identify the instruments of public participation in the budgetary process, as well as to explore their main elements and see if they can be instrumental to "participation in budget deliberations" as per item 2.3.3. of the FT Code in Croatia. It is assumed that Croatian law provides various legal instruments for public participation in the budgetary process that enable the realization of participation principles as established in the FT Code, but also that they are not specific to the budgetary process itself; rather, they are so-called general legal instruments of public participation applicable in the law-making process and the process of adopting other regulations.

Following the introduction, the second section offers definitions and a brief overview of the forms and levels of participation. We also show how participation is connected with fiscal transparency, which is here seen in the context of the state budget, as well as its significance and effects on a country's economy. The third section talks about the significance and practices of the budgetary process as provided by the FT Code and briefly discusses the open budget index as an international comparative indicator of budget transparency, participation and oversight. Section four identifies the instruments of public participation in the budgetary process in Croatia and analyses what constitutes them. Finally, our conclusions are set out in section five.

\section{ABOUT PUBLIC PARTICIPATION}

Public participation in the budgetary process is a manifestation of political participation, consisting of "taking part in the process of formulation, passage and implementation of public policies" concerned with "action by citizens which is aimed at influencing decisions which are, in most cases, taken by public representatives and officials" (Axford et al., 2002:102).

In the pages that follow, we will briefly introduce the notion of public participation, its forms and its levels, as well as its role within the framework of fiscal transparency.

\footnotetext{
${ }^{8}$ To use the definition contained in the Convention on Access to Information, Public Participation in DecisionMaking and Access to Justice in Environmental Matters (the Aarhus Convention, the text of which is contained in the Act Ratifying the Convention on Access to Information, Public Participation in Decision-Making and Access to Justice in Environmental Matters), the term "the public" means one or more natural or legal persons, their associations, organizations or groups. To find out more about the etymological, historical and theoretical approach to the public and its role and regulation in Croatian parliamentary law, see Struić: 2017. The budget process is a "system of rules, both formal and informal, governing the decision-making process that leads to the formulation of a budget by the executive, its passage through the legislature, and its implementation" (von Hagen and Harden, 1996:1), while the term budget means the state budget, or a "document estimating the state's revenues and receipts and determining its expenditure and outlays for a given year, in compliance with the law, which is adopted by the Croatian Parliament" as per Article 3 item 5 of the Budget Act.
} 
The term public participation in the context of fiscal policy ${ }^{9}$ has not been unambiguously defined in professional literature and is still vague (de Renzio and Wehner, 2015:4). The reasons for this could be the fact that the development of participation as a dimension of fiscal transparency is a relatively recent event and that there are numerous activities that fall under its scope (Petrie, 2011:26), but it could also be due to the fact that research dealing in this topic is scarce. For the purpose of this paper, we used the definition by de Renzio and Wehner (2015:9) who define public participation in the budgetary process as "a wide set of possible practices through which citizens, civil society organizations, and other non-state actors interact with public authorities to influence the design and execution of fiscal policies".

Forms and levels of participation. According to Bräutigam (2004:654) public participation in the budget can take many forms: it can be (a) direct (such as when citizens "meet, debate fiscal priorities, and forward their conclusions to decisionmakers"), and (b) indirect (electing members of parliament). Fölscher (2010:41), furthermore, specifies the difference between consultative participation and empowered participation. In the case of the former, the government provides citizens and their representatives with "the opportunity to be heard, but there is no guarantee that participation will be heeded", meaning that "decision-makers have the freedom to agree with citizens or not". When it comes to the latter, the participants are "invested with decision-making power" (right) "and influence, such as having citizen representatives on boards that oversee local public services". Generally speaking, literature does not offer a list of forms of public participation in the budgetary process. This is partially due to their (growing) number, insufficiently clear differences, and scarce research on the topic.

Since the subject matter of this paper are the legal instruments of public participation in the budgetary process, some forms of public participation are noted only as an example (such as round tables and working groups), while the noted public participation levels (degrees) are in accordance with the Code of Good Practice on Consultation with Interested Public in Procedures of Adopting Laws, Other Regu-

\footnotetext{
${ }^{9}$ According to Jurković (1989:1-2) there is no unique definition of fiscal policy or a unique attitude regarding its role. He offers a broad definition of fiscal policy as "premeditated use of fiscal system instruments, i.e. public revenue and expenditure instruments in order to achieve any economic policy goals", noting that one must have in mind the various effects of taxation and public financing of final consumption on the "state and trends in the economy" when evaluating the role and efficiency of fiscal policies. According to Jurković, the easiest and "in fact the only way to comprehend fiscal policy is to observe it in the context of overall economic policy" (Jurković, 2002:184), noting the need to differentiate between its practical aspect which includes "actual economic policy measures undertaken in a specific moment" and its theoretical aspect which is concerned with the scientific discipline "investigating the role, character and effects of those measures in order to establish the principles and criteria guiding policy decision-makers in practice" (Jurković, 1989:1). Babić (1995:232) defines fiscal policy as "changes in public revenue and expenditure with a view of accomplishing a satisfactory rate of growth and price stability", while Blanchard (2011:48) concisely describes fiscal policy as "the choice of taxes and spending by the government".
} 
lations and Acts (hereinafter: the Consultation Code) which specifies four levels (degrees) $)^{10}$ of participation - information, consultation, involvement and partnership.

Before we set out to examine the significance of public participation in the budgetary process, we will clarify the relationship between public participation and fiscal transparency.

\subsection{PUBLIC PARTICIPATION IN THE CONTEXT OF FISCAL TRANSPARENCY}

Justice and Dülger (2009:263) note that there can be no meaningful, i.e. "authentic" public "participation in budgeting without effective transparency". They go on to explain that participation is meaningless if participants are not well informed, "and participants can only be well informed if there is effective transparency". Something similar is noted in Fölscher (2010:14), who observes that the "lack of transparency undermines accountability and prevents participation", as well as in Ott et al. (2016:10), who point out that "the public can effectively participate only if they have access to complete and timely information on the budget and budget process, and if mechanisms are in place to enable such participation." According to Petrie (2011:6), fiscal transparency is a category, an umbrella term that includes the public availability of information, the clarity of roles, accountability and participation as dimensions of transparency. It follows that fiscal transparency is a precondition for participation, its conditio sine qua non; however, public participation is, simultaneously, one dimension of fiscal transparency. All in all, without transparency there is neither inclusion nor participation, and also no accountability (Musa, Bebić and Đurman, 2015:420), meaning that a non-transparent government cannot be considered as legitimate, accountable or efficient (Musa, 2014:18).

The significance of public participation and its effects on the economy. Considering the close connection between public participation and fiscal transparency, Fornes (2014:16) points out that there is evidence that they improve a country's economy, since transparency and public participation "can help control leaks and improve allocation of public spending" as well as to "promote equality between resources and national priorities", where transparency can help the government "to obtain international credit at a lower cost". According to Ott et al. (2016:1) citizens who have obtained "complete, accurate, timely and understandable budget information" can "contribute to the more efficient collection of public funds and supply of public goods and services, thus increasing accountability of the Government and local government authorities and reducing opportunities for corruption".

Reviewing evidence on the impact of fiscal openness, which they consider to be a set of principles and practices concerning both transparency and participation in fiscal matters, de Renzio and Wehner (2015:33-35) list and elaborate a number of

\footnotetext{
${ }^{10}$ The International Association for Public Participation identifies five levels of participation: three are the same as those in the Consultation Code (inform, consult, involve), the fourth level - collaborate - corresponds to the partnership level from the Consultation Code. Empowerment is the highest level, where final decisionmaking is placed in the hands of the public (IAP2, 2014).
} 
studies and findings regarding the macro-fiscal impacts of fiscal openness ${ }^{11}$ and research on how fiscal openness is associated with changes in resource allocation, delivery of public services, and governance and development outcomes ${ }^{12}$.

Moreover, Heimans (2002:9) points out that participation reduces corruption and clientelism, as well as that participation leads to citizens having more trust in institutions and to increased democratisation of the formulation of macroeconomic policy which may, by way of public learning about the key "resource allocation decisions facing governments", lead to "more realistic public expectations about what governments can deliver through budget policy". However, Heimans also notes that public participation can slow down the budgetary process, especially when the government lacks (expert) personnel and/or funds, which leads to "delays in the passage of the budget" - what is more, if the government is unable to provide the public with "timely, useful and accessible budget information, participation and external scrutiny of the budget will in fact be hindered" (Heimans, 2002:18-19), making participation truly counterproductive.

In a word, public participation is of exceptional importance not only because it enables the public to have a say in the design and execution of fiscal policy, but also because participation, along with fiscal transparency, has a substantial impact on a country's economy.

\section{BUDGETARY PROCESS IN THE CONTEXT OF FISCAL TRANSPARENCY: THE EXAMPLE OF THE REPUBLIC OF CROATIA}

According to Rubin (2006:140), the budgetary process requires clearly defined but neutral rules (independent of political interests), providing a "forum for the articulation, discussion and resolution of necessary policy issues". The significance of the budgetary process for a country and a country's economy is visible in at least three aspects: first, decisions on the collection and spending of public funds are made in the course of budget preparation and adoption; second, in the course of this process the government defines the overall budget plan and plans the allocation of funds; and third, the allocation of funds ensures efficient governance (The Treasury of the New Zealand, 1996:124). It is also important to consider its constitutional significance since, according to Article 104, par. 1 of the Croatian Constitution (hereinafter: the Constitution), the President of the Republic has the power of dissolution of the Croatian Parliament (hereinafter: the Parlia-

\footnotetext{
${ }^{11}$ For instance, they refer to the study by Alt and Lassen (2006:13) who "find large swings in the budget balance in low-transparency countries": in those countries, "deficits are more than 1\% of GDP lower in a postelection year than in an election year", while the "dampening effect of transparency on electoral cycles over time leads to lower levels of public debt". According to Hameed (2005), who examines a sample of 32 countries, increasing transparency is associated with better credit rating and related variables such as external debt and deficit levels. Similar results were obtained by Arbatli and Escolano (2012:13-14) who confirmed, in a sample of 56 countries, the association between higher transparency and better ratings, and a correlation suggesting that budget transparency works indirectly through its effect on fiscal outcomes for developed countries, whereas the effect on credit ratings is direct for developing countries.

${ }^{12}$ They mention, for example, a study by Bellver and Kaufmann (2005) about the impact of fiscal openness on corruption reduction and a study by Gonçalves (2014), who posits that "citizen participation allows for better targeting of public policies and spending", which affects resource allocation and spending efficiency.
} 
ment) if the Parliament fails to adopt a budget at the end of the budgetary process, within 120 days from proposing the budget ${ }^{13}$. According to Bratić (2010:136), since the budgetary process is carried out according to an "established pattern and strictly defined rules", it is of utmost importance that all taxpayers "understand the budgetary procedure in its entirety, so that they could have a say in the allocation of budget funds".

FT Code practices. Since "the fundamental precondition for citizen participation is the prompt accessibility of accurate and intelligible budgetary and fiscal information", in other words, the transparency or openness of the budget ${ }^{14}$, the fiscal system and the whole of the public sector (Ott and Bronić, 2015:2), we will briefly explain the practices involved as described by the FT Code. Namely, in order to effectuate the principle of public participation - according to which "the government provides citizens with an accessible summary of the implications of budget policies and an opportunity to participate in budget deliberations" - the FT Code contains guidelines in the form of a description of basic, good, and advanced practices. In order to act according to basic practices, the "Government publishes an accessible description of recent economic and fiscal performance and prospects, as well as a summary of the implications of the budget for a typical citizen". To act according to good practices, the Government, in addition to the above, should publish an accessible and "detailed account of the implications of the budget for a typical citizen" and provide citizens with a "voice in budget deliberations". The third and highest level is advanced practice, pursuant to which the Government should publish "an accessible description of recent economic and fiscal performance and prospects and a detailed account of the implications of the budget for different demographic groups", as well as provide citizens with a "voice in budget deliberations".

The example of Croatia - open budget index. According to Ott and Bronić (2015a:95-96) "Croatia does not at present meet even the basic-practices criterion" when it comes to public participation. Namely, as a part of Government's commitments as per the Open Government Partnership (OGP) ${ }^{15}$, one of the fundamental principles of which is citizen participation, the Ministry of Finance has since 2012 been publishing budget guides for citizens, but without providing a

\footnotetext{
${ }^{13}$ The budgetary process in the Republic of Croatia is implemented in accordance with the Budget Act and the Standing Orders of the Croatian Parliament (hereinafter: Parliament Standing Orders). All three stages of the process (preparation of the draft budget, adoption of the budget and budget execution) take approximately two and a half years. The steps involved in all three phases of the budgetary process are outlined in Articles $22-60$ of the Budget Act.

${ }^{14}$ According to Bađun (2009:495) budget transparency is the "complete, timely and systematic publication of all relevant fiscal information". She notes that the IMF uses the notion of fiscal transparency and defines it as "being open to the public about the government's past, present, and future fiscal activities, and about the structure and functions of government that determine fiscal policies and outcomes".

${ }^{15}$ Open Government Partnership is a multilateral initiative that aims to ensure specific improvement in transparency and openness of public authorities, engage and empower citizens and civil society, fight against corruption, and use new technologies for the improvement of service quality provided to the citizens by the public administration; for more information, see: https:/udruge.gov.hr/partnerstvo-za-otvorenu-vlast-271/271.
} 
summary of the implications of the budget for the average citizen ${ }^{16}$. In that sense, Ott et al. (2016:9-10) note that, according to the Open Budget Index (OBI) ${ }^{17}$ for $2015^{18}$, calculated by the International Budget Partnership (IBP) ${ }^{19}$ for 102 countries, "Croatia's central government budget transparency deteriorated". Namely, the average OBI score in 2015 was 45, meaning that the citizens of 102 countries have access to an average of only $45 \%$ of information on government revenue and expenditure in key budget documents; the OBI score for Croatia in 2015 was 53, or 8 less than in $2012^{20}$, ranking Croatia among countries providing "limited budget information". This is mostly due to the fact that the 2014 budget proposal "failed to include information on revenue and expenditure outturns for the years preceding the budget year" under consideration, which seriously hampered the analysis of the budget proposal. This means that the Government has not made available sufficient information for the public to effectively monitor the state budget spending and can therefore be held accountable for the policies it implements (for more information, see: Bronić and Urban, 2015:2).

Aside from the OBI score, two more results of the 2015 Open Budget Survey (OBS) (IBP, 2015a) for Croatia stand out. The score for public participation is 38 (out of 100) ${ }^{21}$, noting that the Government is weak in providing the public with opportunities to engage in the budget process $^{22}$. In light of the above, Bronić and Urban (2015:4) note that the body that provides "the most opportunities for the public to participate" is the Parliament, through its committees (the score being 74 of 100), while "considerably less opportunities are provided by the State Audit Office" (the score being 25 out of 100) and the Executive (19 out of 100), pointing out that the State Audit Office, among other things, "failed to establish formal mechanisms for the public to indicate programmes or institutions that should be audited", and "the Executive has failed to put in place effective and credible" formal mechanisms (e.g. surveys, focus groups or public hearings) "to find out the public's opinion" on a state budget proposal or budget outturns. Finally, regarding

\footnotetext{
${ }^{16}$ Citizens' budget guides are available at: http://www.mfin.hr/hr/vodici-za-gradane.

${ }^{17} \mathrm{OBI}$ is the only independent and internationally comparable indicator used for the measurement of the transparency of central government budget, participation and oversight; central government budget meaning "all government budgets except the budgets of local government units" and the budgets of local government budget users (Bronić and Urban, 2015:1). IMF's fiscal transparency ratings before the 2014 review of the FT Code were based on Fiscal Reports on the Observance of Standards and Codes - ROSC. Following the review, the Reports were replaced by the new Fiscal Transparency Evaluation - FTE system to analyse fiscal transparency practices according to the FT Code. For more information, see: IMF (2016).

${ }^{18}$ For the 2015 open budget survey, see: IBP (2015a); for methodology, see: IBP (2015b). The results of the next such survey, to include 115 countries, are expected to be available by the end of 2017 (see: http://www. internationalbudget.org/opening-budgets/open-budget-initiative/open-budget-survey/2017-news).

${ }^{19}$ IBP is a Washington-based non-profit organization conducting research in budget transparency since 2006. It engages independent experts from a number of countries to complete OBI score surveys and calculates the countries' OBI on the basis of such surveys.

${ }^{20}$ Previous scores were: 42 (2006), 59 (2008), 57 (2010), and 61 (2012); for more details, see: http://www. internationalbudget.org/opening-budgets/open-budget-initiative/open-budget-survey/country-info/?country=hr. ${ }^{21}$ The average public participation score for the 102 surveyed countries is only 25 .

${ }^{22}$ Certain weaknesses exist on the local level as well. Only several Croatian towns have some experience with engaging citizens in the preparation of the local budget (e.g. Pazin, Crikvenica, Rijeka and Pula), making it hard to speak about specific models of participatory budgeting in Croatian local units. In most of the cases it is just a consultation process "without real engagement of citizens in the decision-making process on concrete financial sums” (Džinić, Murray Svidroňová and Markowska-Bzducha, 2016:36).
} 
budget oversight, OBS shows that budget oversight by the State Audit Office is adequate (the score being 92 out of 100), while budget oversight by the Parliament is weak (27 out of 100), judging it necessary to establish a specialized budget research office within the Parliament.

According to IBP, the measures necessary to improve participation are: establishing credible and effective mechanisms (i.e. public hearings, surveys, and focus groups), ensuring that the public is informed of the purpose of public budget engagements and provided with sufficient information to participate effectively, and establishing formal mechanisms for the public to assist the State Audit Office to formulate its programme and participate in audit.

With this in mind, and especially since FT Code's principle of participation implies not only the requirement to provide an accessible summary of the implications of budget policies, but citizen participation in budget deliberations as well, we will examine the legal instruments of public participation in the budgetary process in the Republic of Croatia which allow the realisation of that principle.

\section{LEGAL INSTRUMENTS OF PUBLIC PARTICIPATION IN THE BUDGETARY PROCESS IN THE REPUBLIC OF CROATIA}

Since Article 212 par. 1 of the Parliament Standing Orders stipulates that the provisions of the Standing Orders "pertaining to the procedures to enact laws shall be applied accordingly" to the adoption of the central budget - for instance, the provision on the commencement of the enactment procedure (Article 171), receiving and forwarding bills (Article 178), consideration of a bill in working bodies (Article 179), debate on the final draft of a bill (Article 195) and amendments (Article 196-202) - it can be inferred that the legal instruments of public participation in the legislative procedure apply to the budgetary process as well ${ }^{23}$. It should be noted that Struić and Bratić (2017), when studying the normative solutions of public participation in the legislative process through the role of parliamentary working bodies, using the example of the Finance and Central Budget Committee of the Croatian Parliament from the fifth to the eighth parliamentary term, identified the existence of several public participation mechanisms in the legislative process, specifically: the right of initiative to propose laws, i.e. amendments, the right to be informed, the right to advise, and the right to be involved in working groups and bodies.

We will start from these legal mechanisms (instruments) - which can be generally designated as general legal instruments for the purpose of this paper, considering their applicability in both the legislative process and the budget passing process

\footnotetext{
${ }^{23}$ It is worth noting that the Rules of Procedure of the Government of the Republic of Croatia (hereinafter: Government Rules of Procedure) contain no special provisions regarding the budget; rather, Article 30 par. 4 stipulates in a general manner that the central state administration bodies shall, when forwarding draft bills, other regulations and acts to the Government, enclose the relevant reports on consultation with the interested public (only if carried out), while Article 174 par. 4 of the Parliament Standing Orders stipulates that the proposer shall enclose with the submitted bill a report on conducted consultations.
} 
- and analyse in more detail what are their components and if they can be used to accomplish the objective to "participate in budget deliberations" as per item 2.3.3. of the FT Code. Moreover, we will examine if there are, apart from these instruments, any other, special participation instruments, specific to the budgetary process itself.

\subsection{GENERAL LEGAL INSTRUMENTS OF PARTICIPATION}

Implementing the mechanisms of public participation in the legislative process as defined in the aforementioned paper by Struić and Bratić (2017) to the budgetary process, the first mechanism of public participation in the budgetary process that should be mentioned is the right to be informed.

The right to be informed. According to the Consultation Code, informing is the first level of participation, which "assumes a one-way process whereby state authorities" either inform citizens at their own discretion "or citizens obtain information on their own initiative" (e.g. by way of official gazettes, the websites of state bodies, etc.). The right to access to information held by public authorities is guaranteed by Article 38 par. 4 of the Croatian Constitution and more closely defined in the Right of Access to Information Act. According to the Act, public authorities ${ }^{24}$ are obliged to publish many information ${ }^{25}$ "in an easily searchable and machine readable format" on their websites - for instance, documents relevant to the public authority's scope of activity, information on financing sources, the budget, financial plan or other appropriate documents that determine the revenues and expenditures of public authorities, and data and reports on the execution of the budget, financial plans and other appropriate documents (Article 10 par. 1). Additionally, public authorities must inform the public of, among other things, agendas of meetings and sessions of official bodies and their scheduled times, manner of work and possibilities of direct insight into their work (Article 12 par. 1 item 1).

In the context of the right to be informed, we should mention the provisions that enable public representatives to follow public authorities' work and take part in sessions. For example, the Parliament Standing Orders contain several provisions on transparency of work (Articles 279-288), notably provisions on the obligation to inform the public of its work, its decisions and matters debated, and on the possibility for draft acts of Parliament or acts of Parliament to be "published in full in the public media or as separate publications" (Article 279), publishing its bulletin ("Parliament's website shall be considered the official bulletin of Parliament") and other publications (Article 280 par. 1), exempting from publication Parlia-

\footnotetext{
${ }^{24}$ These are, inter alia, state administration bodies, other state authorities, bodies of local and regional selfgovernment units, legal entities and other persons vested with public authority, as well as other bodies as per Article 5 par. 1 item 2 of the Right of Access to Information Act.

${ }^{25}$ According to Article 5 item 5 of the Right of Access to Information Act, the right of access to information encompasses the right of the beneficiary "to seek and acquire information," as well as "the obligation of the public authorities to ensure access to requested information, i.e. to disclose information regardless of the request, when so required by the law or other regulations".
} 
ment documents and materials classified as confidential (Article 281 par. 1) and the possibility to close Parliament working bodies' sessions (or individual parts thereof) to the public (Article 284). The public character of Parliament sessions is noted in Article 84 of the Constitution, as well as in the Rules on the Public Transparency of the Work of Parliament and its working bodies regarding the "presence of representatives of citizens' associations, non-governmental organisations and citizens" as observers at sessions, visits of organised groups of citizens to Parliament, methods of recording and broadcasting Parliament sessions, registering media representatives, and Parliament website content (Article 1).

Moreover, according to Article 9 of the Act on the Government of the Republic of Croatia (hereinafter: Act on the Government), Government sessions are public, but the Government can decide that the public would not be present at the session, i.e. debate on certain items on the agenda; moreover, pursuant to Article 32 item 2, decisions, resolutions and conclusions can be published in the official gazette if the Government decides so when adopting such acts. Furthermore, the transparency of the Government's work is determined in Articles 52-54 of the Government Rules of Procedure, specifically Article 52 item 3 according to which the Prime Minister's Office's Public Relations Service shall issue a statement to the media regarding closed sessions at the latest within an hour after the session is finished (unless the Government decides that the public would not be informed on a particular issue). Government coordination sessions (sessions of its permanent working bodies) are closed to the public (unless decided otherwise by the coordination body chairperson) and there are no audio recordings, while the sessions of Government expert working groups are closed to the public and there are no audio recordings, without exception.

It follows from the above that, in the course of the budgetary process, the public has the right to request (and obtain) one or more pieces of information and that the public authority must enable access to the requested information, i.e. to publish information whether they have been requested or not (if such publication is required pursuant to a law or regulation). Moreover, the public has the right to follow the work of the Parliament, the Government and parliamentary working bodies (such as round tables) and to be present at their sessions, with certain limitations: the public does not have access to confidential documents and materials, and the Government and Parliament working bodies can decide that a session (of a part thereof) would be closed to the public. There are no provisions, however, regarding the criteria for the Government and Parliament working bodies to follow. It should, moreover, be noted that, according to the Report on the Implementation of the Act on the Right of Access to Information for 2016 (Information Commissioner, 2017), there have been "irregularities in dealing with citizens' requests", at all levels and in all kinds of bodies, particularly "with respect to deadlines and the manner of decision-making". Cases of citizens' requests for access to information being ignored are particularly alarming. 
The right to consultation. The public can participate in the budgetary process by exercising its right to being consulted. Within the meaning of the Consultation Code, this is the second level of participation involving "a two-way process" in the course of which state authorities solicit and receive feedback "from citizens and the interested public ${ }^{26}$ in the procedure" for the enactment of laws and the "adoption of other regulations and acts". Pursuant to Article 11 of the Act on the Right of Access to Information, public authorities are obliged to conduct public consultations via their websites or via the central state website for public consultations when adopting regulations and general acts, or other strategic or planning documents where these affect the interests of citizens and legal entities. In other words, these bodies must consult the public by enabling interested individuals or legal entities to deliver their proposals and opinions and by answering them. The proactive approach to the publication of information allows the public to get acquainted with the decisions of public authorities, enabling more transparency and more openness ${ }^{27}$ as well as more efficiency when it comes to the activities of such bodies (for more information, see: Information Commissioner, 2016). For consultation purposes, state administration bodies have at their disposal the central state website for public consultations (e-Savjetovanja), while other public bodies (including local and regional self-government units and legal persons with public authority) can use their websites or the central state website for public consultation, specifically by releasing "the draft of the regulation, general act or other document", along with a "substantiation of the reasons and objectives to be achieved through the adoption of the regulation, act or other document, and inviting the public to submit their proposals and opinions" (Article 11 par. 2). Public authorities "are obliged to conduct public consultations as a rule, for a duration of 30 days"; upon the expiry of the deadline, the public authority is obliged to draft and publish a report on the public consultation, which contains the received proposals and comments, as well as the reasons for their rejection (Article 11 par. 3 and 4). The implementation of these provisions shall be monitored by the Information Commissioner by reviewing citizens' petitions, public authorities' reports, etc.

The report on public consultations plays a significant role according to the Government Rules of Procedure, Article 30 par. 4 of which stipulates that central state administration bodies shall enclose reports on public consultations with the interested public when draft bills, other regulations and acts are submitted to the Government. This provision is applied when public consultations are conducted in accordance with special regulations, i.e. the Consultation Code, but not when they are conducted in accordance with regulations pertaining to regulatory impact

\footnotetext{
${ }^{26}$ According to the Consultation Code, these are "citizens, civil society organizations (informal civic groups or initiatives, associations, foundations, funds, private institutions, trade unions, associations of employers), representatives of the academic community, chambers, public institutions and other legal entities performing a public service or who might be affected by the law, other regulation or act which is being adopted, or who are to be included in its implementation".

${ }^{27}$ Unlike transparency, which is a one-way process enabling citizens to obtain information from public authorities at own request or on the basis of that public authority's initiative, openness is a two-way process where information is offered to citizen, eliciting a feedback in the form of opinions and attitudes of citizens (for more information, see: Đurman, 2016:350-351).
} 
assessment. ${ }^{28}$ Moreover, reporting on conducted consultations with the interested public is mentioned in the Parliament Standing Orders, stipulating in its Article 174 par. 4 that the sponsor shall enclose with the submitted bill a report on consultations with the interested public.

However, according to the Report on the Implementation of the Act on the Right of Access to Information for 2016 (Information Commissioner, 2017) public authorities have not reached a satisfactory level of proactivity in the publication of information which would point to the adoption of transparency as a premise to guide their day-to-day activities. For instance, some public authorities do not update the information on their websites, there have been problems with the format of the documents, website availability and user-friendliness, clarity of published information, etc. Even though the number of conducted consultations has been on the rise, especially on the central level, there is much room for improvement regarding the quality of implementation ${ }^{29}$, particularly regarding the adoption and publication of necessary documents (plans and reports).

Right of initiative. Furthermore, in order to potentially have an impact on the adoption of, or an amendment and/or addition to a regulation, act or document, citizens and other representatives of the public may use the right of initiative pursuant to Article 46 of the Constitution, by virtue of which everyone is "entitled to file petitions and complaints and to submit proposals to governmental and other public bodies, as well as to receive responses thereto". This provision is referenced in Article 44 par. 6 of the Parliament Standing Orders, according to which, "if a petition or proposal for the enactment of legislation or other acts is submitted by citizens to Parliament, then the Speaker of Parliament shall refer it to the chairperson of the relevant working body which shall be obliged to notify the sponsor of the petition or proposal on the outcome of such a petition or proposal within a period not exceeding three months". Apart from this right to legislative initiative, the same instrument allows the public to petition any representative, political group, Parliament working body or the Government (who are authorised to spon-

\footnotetext{
${ }^{28}$ The process of regulatory impact assessment is governed by the Act on Regulatory Impact Assessment. Regulatory impact assessment is a procedure for the "preparation and drafting of draft bills through the analysis of direct impacts, aimed at choosing the optimum legal solution or undertaking other activities and measures" (Article 2 par. 1). Since the Act on Regulatory Impact Assessment applies to the drafting of draft bills (Article 5 par. 1) and since only one specific act is passed under the budgetary process - the Act on the Execution of the State Budget of the Republic of Croatia for the current year - which having in mind the topics it regulates does not fall under the scope of the Act on Regulatory Impact Assessment (Article 15 par. 1 item 3) or has it been included in the Annual Plan of Normative Activities (planning document on draft bills to be submitted to the Government in the course of the budget year (for a list of plans, see: https://zakonodavstvo.gov. $\mathrm{hr} /$ godisnji-plan-normativnih-aktivnosti/229), it will not be referred to in this paper.

${ }^{29}$ Witness to this are, for instance, the results of the Index of Good Governance in Croatia 2012 research, according to which only $14 \%$ of institutions (4 ministries) made an attempt at finding out the opinion of the public on what budgetary priorities should be in 2013, while only two of the 29 analysed institutions (the Government and the Ministry of Finance) made an attempt at finding out the public opinion on their budgets and spending in 2012 or 2013. It has also been noted that the majority of documents for the 29 institutions (budget proposals, enacted budgets, semi-annual financial reports and annual financial reports) can indeed be found on the websites of the Ministry of Finance, Government, Parliament or the Official Gazette, but only as part of summary documents for all budget users (Miošić, Bronić and Škrabalo, 2013:25-28).
} 
sor amendments) to table amendments. However, it is usually unclear from the proposal of the act or the amendment if representatives of the public participated in their formulation (or, if yes, in which way and to what extent) ${ }^{30}$, making it difficult to determine the frequency (and efficiency) of the use of this public participation instrument in the budgetary process.

It is also important to note that the Consultation Code - a document that has been harmonized with a number of international documents, such as the Code of Good Practice for Civil Participation in the Decision-Making Process (Council of Europe, 2009) - stipulates the minimum standards and measures ${ }^{31}$ for conducting consultations with the interested public when drafting a regulation or act (resolution, declaration, strategy, programme, etc.) through which the policy of the Croatian Parliament or the Government is expressed, and for whose drafting the central state administration bodies and offices of the Government are competent. However, as Ott and Bronić (2015a:36) point out, the scope of the Consultation Code has not been "extended to the budgetary process and the budget is formulated and presented in a relatively closed procedure", while key budgetary documents such as budget proposals and semi-annual and annual reports on state budget have not been discussed. Yet, since the instruments of public participation in the course of the enactment of laws apply to the budgetary process and since the Consultation Code is to be applied in the procedure to enact laws, other regulations and acts including the state budget - it follows that the general principles, standards and measures for consultations with the interested public stipulated in the Consultation Code should be applied to the budgetary process. On the other hand, it should be borne in mind that the Consultation Code is not legally binding, meaning that the failure to implement it does not result in sanctions, and that the deadline for consultations according to the Consultation Code is only 15 days, unlike the deadline for consultations set out in the Act on the Right of Access to Information.

The right to be involved. The third level of public participation, according to the Consultation Code, is involvement, which "assumes a higher level in the two-way process" through which citizens and other "representatives of the interested public are actively involved in the creation of public policies, for example through membership in working groups". In this context, it is worth noting the provisions of the Government Rules of Procedure and the Parliament Standing Orders regarding the right to be involved, as the fourth key instrument of public participation in the budgetary process. According to the Parliament Standing Orders, the public can participate on the basis of the provisions on the establishment of special working groups by virtue of the decision of the chairperson of a working body (Article 53 item 1), invitation of public officials, scholars and professionals and other persons

\footnotetext{
${ }^{30}$ Compare with Struić and Bratić, 2017:138.

${ }^{31}$ Pursuant to Chapter V item 1 of the Consultation Code, this means timely information about the plan for the enactment of laws, access to and clarity of the content of the consultation process, the time limit for its implementation, feedback information about the effects of the consultations conducted and the harmonization of the application of standards and measures of conducting consultations in state bodies.
} 
to meetings of working bodies in order to obtain their opinions on matters being discussed (Article 57 par. 1), including scientific and other organisations and individual experts in the preparation of acts or the consideration of certain matters within the competence of the working body if the relevant funds are secured (Article 52), and the appointment of public officials, scholars and professionals "to working bodies with all the rights pertaining to members of working bodies, with the exception of the right of decision-making" (Article 57 par. 3). ${ }^{32}$ Government Rules of Procedure contain but one provision on public involvement, specifically the one regarding the possibility to invite established experts in certain areas to Committee sessions, i.e. Government coordination group in order to provide expert opinions (Article 21 item 6).

Moreover, the Decision on the Establishment of a Commission on Fiscal Policy ${ }^{33}$, consisting of six members (representatives of certain institutions ${ }^{34}$ appointed by the Parliament) and the president of the Parliament's Finance and Central Budget Committee presiding over the Commission on Fiscal Policy, contains provisions on public involvement. Apart from the representatives of those institutions, other persons can participate in the activities of the Commission on Fiscal Policy (take part in the discussions, without having voting rights), and the Commission on Fiscal Policy can hire external experts for the drafting of the Fiscal Policy Assessment Report (Article 25 item 1 and 2 of the Rules of Procedure of the Commission on Fiscal Policy). Even though Commission sessions are, as a rule, closed to the public, it can adopt a special decision by virtue of which a session becomes open to the public (Article 20 item 1 and 2 of the Rules of Procedure of the Commission on Fiscal Policy).

Partnership. Even though the Consultation Code provides a fourth level of public participation, partnership - as "the highest level of cooperation and mutual responsibility of the Government and representatives of the interested public in the process of adoption and implementation of programmes, laws, other regulations and acts" (Chapter III par. 1 subpar. 4) - the research in the area of legal instruments of public participation in the legislative procedure has shown that this level has not yet been reached since there lacks the aspect of codecision as a precondition for the implementation of that level of participation in the legislative procedure (Struić and Bratić, 2017:144). If we exempt the abovementioned example of the Commission on Fiscal Policy, where decisions are made by a majority vote of all of its members (including the votes of the representatives of certain institutions appointed by the Parliament) - but not of other persons who might

\footnotetext{
${ }^{32}$ For more information, see: Struić and Bratić, 2017:142-144.

${ }^{33}$ According to Chapter I of the Decision, the Commission on Fiscal Policy (hereinafter: Commission) is a professional and independent body the aim of which is to improve the public finance system and to monitor the application of fiscal rules as determined in the Fiscal Responsibility Act in order to contribute to "ensuring and maintaining fiscal discipline, transparency and mid-term and long-term sustainability of public finance". ${ }^{34}$ These are the representatives of the State Audit Office, the Zagreb Institute of Economics, the Institute of Public Finance, Croatian National Bank, and business and law schools. These institutions choose their representatives among established scientists and experts possessing a certain level of education, professional knowledge, and professional experience in the area of public finance, macroeconomics, economic policy, and accountancy.
} 
participate in its activities - the lack of this precondition in the legislative procedure should in principle be sought in the budgetary process as well, since the public officials, scholars and professionals appointed to Parliament working bodies have no decision-making rights, and neither do other persons who might be invited to participate in a session of a Parliament working body or a Committee session, i.e. Government coordination group to provide professional opinions.

\subsection{SPECIAL LEGAL INSTRUMENTS OF PUBLIC PARTICIPATION}

Even though a number of regulations establishing various instruments of public participation in the legislative procedure and the budgetary process has been mentioned, these regulations make no mention of special participation instruments particular to the budgetary process.

Another important aspect of the legal framework governing this issue is the Agreement on the Establishment of the Economic and Social Council (ESC) ${ }^{35}$. The Agreement stipulates, among other things, that the ESC, which represents the highest form of tripartite social dialogue in the Republic of Croatia, shall evaluate and offer its opinion on the measures aimed at macroeconomic stability, economic competitiveness, and a balanced economic and social development, and offer its opinion regarding the budget proposal and proposals for acts in the area of labour, economy, and social security. It also discusses and can offer its opinion on proposals for other acts and regulations of public interest (Article 10). Even though the Agreement may look like a special legal instrument of participation, since it expressly allows that the ESC offer an opinion on the budget proposal, we should note that it is in fact a general legal instrument since the ESC also offers opinions regarding proposals for acts, meaning that the Agreement is not, in its essence, a special instrument of participation particular to the budgetary process.

Even though consultation between Government representatives and social partners under the ESC aimed at offering opinions on the budget proposal could be interpreted as consultation ${ }^{36}$, according to some authors, they do not represent public participation. Namely, according to Ott and Bronić (2015a:32), "citizens are not included in that stage, although the Government deems them to be included", as they can influence policies and consequently indirectly the budget through public consultations in line with the Consultation Code. They, however, point out that ESC opinions cannot be considered as participation in the formulation of the budget and that this represents but a formal fulfilment of obligations set out in the Agreement because the discussion with social partners takes place only after the final state budget draft is adopted by the Government. According to the

\footnotetext{
${ }^{35}$ ESC is composed of Government representatives and social partners (higher-level employers' associations and higher-level union associations). They may commence consultation before drafting specific documents. ${ }^{36}$ Consultation in this context can include, e.g. the principle of offering comments as per Article 79 par. 2 of the Act on the State Administration System, according to which "ministers, secretaries of central offices, and directors of state administration organisations may decide that the drafts of those regulations in the preparation of which the public is particularly interested shall be published in mass media, and also invite all interested parties to give their comments regarding the draft of such regulations".
} 
Croatian Association of Counties, this is suggested by the fact that there are 2 to 3 state budget amendments per year, "supported by all counties, but none has ever been adopted by the Parliament" (Ott and Bronić, 2015a:36).

In a word, the public has the right to informing, consultation, initiative, and involvement, while the right to partnership is limited to the possibility of participation through the Commission on Fiscal Policy, where decisions are adopted by a majority vote of all of its members (not including other persons who might participate in its activities). Apart from the latter example - the Commission on Fiscal Policy - the public does not have codecision powers in the budgetary process, which is one of the preconditions for the implementation of this highest level of participation according to the Consultation Code. Finally, regulations providing the aforementioned general legal instruments do not contain special instruments of participation specific for the budgetary process itself.

\section{CONCLUSION}

The final review of the FT Code from 2014 introduces the principle of participation which is to be applied in the Republic of Croatia due to the fact that Croatia is an IMF member. With that in mind, as well has bearing in mind the fact that public participation, as one facet of fiscal transparency, is becoming part of an increasing number of international documents, this paper closely analyses the legal instruments of public participation in the budgetary process in Croatia. First, an interdisciplinary approach has demonstrated the significance and economic effects of public participation in the budgetary process, identified the instruments of public participation in the process, and investigated their components and whether they can lead to "an opportunity to participate in budget deliberations" as per item 2.3.3. of the FT Code in the Republic of Croatia. The assumption was made that there were various legal instruments of public participation in the budgetary process in the Croatian law which would enable the implementation of the participation principle set out in the FT Code, as well as that they were not specific to the budgetary process itself but were rather general legal instruments of participation applied in the law-making process and the process of adopting other regulations.

Namely, it has been found that the provisions of the Parliament Standing Orders pertaining to the procedures to enact laws are applied to the passage of the central budget (Article 212 par. 1 of the Parliament Standing Orders), which has led to the conclusion that the legal instruments of participation in the law-making process are applicable in the budgetary process as well. With that in mind and based on earlier research into the normative solutions for public participation in the lawmaking procedure through the role of parliamentary working bodies, finding that there were several instruments of public participation in place in the law-making procedure which can, in principle, be defined as general legal instruments, the authors analysed their nature in more detail and sought to find out whether they could correspond to instruments of "participation in budget deliberations" as per item 2.3.3. of the FT Code. Moreover, the authors have looked into the potential 
existence of other, special legal instruments of participation, specific to the budgetary process itself.

It has been found that the public has the right to be informed, to be consulted, the right of initiative, and the right to involvement, while the right to partnership was limited to the possibility of participation in decision-making in the Commission on Fiscal Policy. The right to be informed means not only the right to access information, which can be requested at any stage of the budgetary process, but the proactive publication of information by public authorities throughout the budgetary process as well. The right to be consulted can be claimed only in the procedure of the adoption of regulations and acts or other strategic or planning documents that have an impact on the interests of citizens and legal entities, in accordance with the Act on the Right of Access to Information and the Consultation Code. The third instrument, the right of initiative, can be employed within the context of the Parliament, regarding the possibility granted by the Parliament Standing Orders for a parliamentary working body to discuss petitions and proposals, take them into account and, eventually, implement them in the regulation, act, or document in question. Within the context of the right to involvement, the public has the opportunity to participate by way of membership in special working groups (but only when this has been allowed by virtue of the decision on the establishment and appointing the members of a working group, made by the chairperson of the working body), as experts or representatives of scientific and other organizations (only under the condition that the relevant funds are secured) and as public officials, scholars and professionals (only when appointed by the Parliament), or Commission on Fiscal Policy members, i.e. representatives of particular institutions appointed by the Parliament (one member per institution). Since the aforementioned are general legal instruments of participation which are applicable in both the law-making procedure and in the budgetary process, and considering the fact that the instruments enabling an opportunity "to participate in budget deliberations" as per item 2.3.3. of the FT Code have not been precisely defined in the FT Code, it could be concluded that representatives of the public can use any of the aforementioned instruments in the course of the budgetary process in order to implement the principles of participation according to the FT Code, but only taking into account the constraints imposed by the regulations introducing those instruments.

There is a fourth level of public participation according to the Consultation Code, partnership, which implies the possibility of codecision within a Commission on Fiscal Policy, where decisions are made by a majority vote of all its members (in other words, including the representatives of certain institutions appointed by the Parliament, but excluding other persons that may participate in its activities). However, except in the latter case, the public has no codecision powers in the budgetary process, even though codecision is a precondition for the implementation of this highest level of participation. Namely, public officials, scholars and professionals appointed to parliamentary working bodies have no decision-making rights, and neither do other persons who might be invited to a parliamentary 
working body session or a Committee meeting, i.e. a Government coordination group session, to offer expert opinions. Finally, the regulations that provide the aforementioned general legal instruments do not offer special instruments of participation particular to the budgetary process itself.

Having identified the available instruments and determined the possibilities to participate in the budgetary decision-making process in line with the FT Code, several potential problems have been identified regarding their efficient application in practice, such as the fact that the Consultation Code is not legally binding and the failure to implement its provisions does not result in sanctions (it could only possibly raise the issue of political responsibility), or the inexistence of particular criteria when the Government and a parliamentary working body decide to close a (part of) a session to the public. Those and other potential issues - such as those mentioned when talking about the Report on the Implementation of the Act on the Right of Access to Information for 2016 - could lead to the assumption that there is some room to improve the current legal instruments of participation, but this issue should be analysed separately. Namely, if one bears in mind that the 2015 OBI score for Croatia was 38 (out of 100) and that the Ministry of Finance has been publishing budget guides for citizens since 2012, which, however, do not contain a summary of the budget's impact on the average citizen, it could be assumed that the true and full application of the public participation principle as defined in the FT Code by way of the legal instruments analysed in this paper is still some way away.

Finally, while taking into account the fact that further research is necessary to analyse the ways to improve the current legal instruments of participation, as noted above, it is worth mentioning some possible approaches to that end and formulate some general recommendations based on the research presented in this paper. The first option is to adopt a new Consultation Code that would explicitly include the budgetary process and be harmonized with the Act on the Right of Access to Information. However, one should keep in mind that the Consultation Code is applicable to the budgetary process without the need for this to be explicitly noted (since the Consultation Code is not only applied in the law-making process, but also in the process of making other regulations and acts, which includes the central budget). Moreover, the legal principle of lex superior derogat legi inferiori, according to which a higher-level regulation (Act on the Right of Access to Information) overrides a lower-level regulation (Consultation Code), could suffice when it comes to the contradictory provisions of the two.

Moreover, a dedicated act - a code of fiscal transparency which would impose the obligation to strengthen fiscal transparency and participation in accordance with a number of international documents mentioned herein and particularly with the FT Code - should be drafted and adopted by the Government. Additionally, a set of guidelines for its implementation should be devised to guide not only the representatives of government bodies involved in the budgetary process, but the public 
at large as well. Furthermore, the possibility to amend and/or make additions to the Government Rules of Procedure and the Parliament Standing Orders to determine the criteria under which the Government and Parliament working body can decide to close (a part of) a session to the public, among other things, should be considered, as should the option to strengthen partnership, the fourth level of public participation, by explicitly extending the codecision powers to (at least) working groups, for instance.

Apart from the above solutions which focus on the legal framework, the issue of its application in practice is significant, as well. Namely, as mentioned above, many problems are present in practice, particularly when it comes to the Report on the Implementation of the Act on the Right of Access to Information for 2016. These are, for instance, irregularities in dealing with citizen requests and ignoring their petitions, or the irregular updating of public authorities' websites. The solutions should be part of a comprehensive approach which would include not only the abovementioned options to intervene within the legal framework but to intervene on the level of all government bodies involved in the budgetary process as well (e.g. training for staff, encouraging cooperation and coordination among and within government bodies, increasing their capacities). Moreover, this approach should include continuous activities aimed at strengthening citizens' awareness of the importance of participation in the budgetary process, as well as the role of the legal instruments covered herein and how to use them. Without such a comprehensive approach, the full implementation of the FT Code principles of participation will be impossible to achieve.

\section{Disclosure statement}

No potential conflict of interest was reported by the authors. 


\section{REFERENCES}

1. Act on Regulatory Impact Assessment (Zakon o procjeni učinaka propisa), NN 44/17.

2. Act on the Government of the Republic of Croatia (Zakon o Vladi Republike Hrvatske), NN 150/11, 119/14, 93/16.

3. Act on the Right of Access to Information (Zakon o pravu na pristup informacijama), NN 25/13, 85/15.

4. Act on the State Administration System (Zakon o sustavu državne uprave), NN 150/11, 12/13, 93/16, 104/16.

5. Act Ratifying the Convention on Access to Information, Public Participation in Decision-Making and Access to Justice in Environmental Matters (the Aarhus Convention (Zakon o potvrđivanju Konvencije o pristupu informacijama, sudjelovanju javnosti u odlučivanju i pristupu pravosuđu u pitanjima okoliša (tzv. Arhuška konvencija)), NN-Međunarodni ugovori, 1/07.

6. Agreement on the Establishment of the Economic and Social Council (Sporazum o osnivanju Gospodarsko-socijalnog vijeća), NN 89/13.

7. Alt, J. E. and Lassen, D. D., 2006. Fiscal transparency, political parties, and debt in OECD countries. European Economic Review, 50 (6), pp. 1403-1439. doi: 10.1016/j.euroecorev.2005.04.001

8. Arbatli, E. C. and Escolano, J., 2012. Fiscal Transparency, Fiscal Performance and Credit Ratings. IMF Working Paper, No. 12/156.

9. Aristotel, 1988. Politika. Zagreb: Globus [etc.].

10. Axford, B. [et al.], A., 2002. Uvod u politologiju. Zagreb: Politička kultura.

11. Babić, M., 1995. Makroekonomija. Zagreb: Mate.

12. Bađun, M., 2009. Budget transparency. Financial Theory and Practice, 33(4), pp. 495-497.

13. Belgian Constitution, 1831. Available at: $<$ http://modern-constitutions.de/BE00-1831-02-07-fr-i.html>.

14. Belgian Constitution, 2014. Available at: $<$ https://www.dekamer.be/kvvcr/pdf sections/publications/constitution/GrondwetFR.pdf>.

15. Bellver, A. and Kaufmann, D., 2005. Transparenting Transparency: Initial Empirics and Policy Implications. Paper presented at the IMF Conference on Transparency and Integrity, July 6-7, 2005, Washington, D.C.

16. Blanchard, O., 2011. Makroekonomija. Zagreb: Mate; Zagreb School of Economics and Management.

17. Bratić, V., 2010. Politika proračuna i proračunskog procesa: primjer Hrvatske. Anali Hrvatskog politološkog društva: časopis za politologiju, 7(1), pp. 123-143.

18. Bräutigam, D., 2004. The people's budget? Politics, participation and propoor policy. Development Policy Review, 22(6), pp. 653-668. doi: 10.1111/ j.1467-7679.2004.00270.x

19. Bronić, M. and Urban, I., 2015. National budget transparency - a deterioration in the quality and comprehensiveness of government revenue and expenditure information. Press Releases (85). doi: 10.3326/pr.2015.85 
20. Budget Act (Zakon o proračunu), NN 87/08, 109/07, 136/12, 15/15.

21. Code of Good Practice on Consultation with Interested Public in Procedures of Adopting Laws, Other Regulations and Acts (Kodeks savjetovanja sa zainteresiranom javnošću u postupcima donošenja zakona, drugih propisa i akata), NN 140/09.

22. Council of Europe, 2009. Code of good practice for civil participation in the decision-making process.

23. Croatian Parliament Standing Orders (Poslovnik Hrvatskoga sabora), NN 81/13, 113/16, 69/17.

24. de Renzio, P. and Wehner, J., 2015. The Impacts of Fiscal Openness: A Review of the Evidence. Global Initiative on Fiscal Transparency. doi: 10.2139/ ssrn.2602439

25. Decision on the Establishment of a Fiscal Policy Committee (Odluka o osnivanju Povjerenstva za fiskalnu politiku), NN 156/13.

26. Drezgić, S., 2006. Fiskalna transparentnost RH u kontekstu pristupanja EU. Riznica, (5), pp. 25-30.

27. Đurman, P., 2016. Europeizacija javne uprave i načelo otvorenosti. Godišnjak Akademije pravnih znanosti Hrvatske, 8(1), pp. 342-373.

28. Džinić, J., Murray Svidroňová, M. and Markowska-Bzducha, E., 2016. Participatory Budgeting: A Comparative Study of Croatia, Poland and Slovakia. NISPAcee Journal of Public Administration and Policy, 9(1), pp. 31-56.

29. Fiscal Responsibility Act (Zakon o fiskalnoj odgovornosti), NN 139/10, $19 / 14$.

30. Fölscher, A., 2010. Budget transparency: New frontiers in transparency and accountability. London: Open Society Foundation.

31. Fornes, G. D., 2014. The current state and development of budget transparency. Castellón: Universitat Jaume I.

32. French Constitution, 1791. Available at: <http://www.conseil-constitutionnel. fr/conseil-constitutionnel/francais/la-constitution/les-constitutions-de-lafrance/constitution-de-1791.5082.html>.

33. GIFT, 2012. High Principles on Fiscal Transparency. Global Initiative on Fiscal Transparency.

34. GIFT, 2015. Principles of Public Participation in Fiscal Policy. Global Initiative on Fiscal Transparency.

35. GIFT, 2017a. Principles of Public Participation in Fiscal Policy. Global Initiative on Fiscal Transparency.

36. GIFT, 2017b. High-Level Principles on Fiscal Transparency, Participation and Accountability. Global Initiative on Fiscal Transparency.

37. Gonçalves, S., 2014. The Effects of Participatory Budgeting on Municipal Expenditures and Infant Mortality in Brazil. World Development, 53, pp. 94110. doi: 10.1016/j.worlddev.2013.01.009

38. Government of the RC, 2017. Plan zakonodavnih aktivnosti. Zagreb: Governemnt of the Republic of Croatia. 
39. Government Rules of Procedure (Poslovnik Vlade Republike Hrvatske), NN 154/11, 121/12, 7/13, 61/15, 99/16, 57/17.

40. Hameed, F., 2005. Fiscal Transparency and Economic Outcomes. IMF Working Paper, WP/05/225. Washington: International Monetary Fund.

41. Heimans, J., 2002. Strengthening Participation in Public Expenditure Management: Policy Recommendations for Key Stakeholders. OECD Development Centre Policy Brief, No. 22. doi: 10.1787/640564834060.

42. IAP2, 2014. IAP2's public participation spectrum.

43. IBP, 2015a. Open Budget Survey 2015. Washington: International Budget Partnership.

44. IBP, 2015b. Open Budget Survey 2015. Methodology. Washington: International Budget Partnership.

45. IBP, 2016. Open budget survey document availability tracker-Croatia. Washington: International Budget Partnership.

46. IMF, 2014. The fiscal transparency code. Washington: International Monetary Fund.

47. IMF, 2016. Standards and Codes: The Role of the IMF. Washington: International Monetary Fund.

48. Information Commissioner, 2016. Izvješće o provedbi Zakona o pravu na pristup informacijama za 2015. godinu. Zagreb: Information Commissioner.

49. Information Commissioner, 2017. Izvješće o provedbi Zakona o pravu na pristup informacijama za 2016. godinu. Zagreb: Information Commissioner.

50. IPF, 2014. MMF: Kodeks fiskalne transparentnosti. Newsletter (91). doi: $10.3326 /$ nlh.2014.91

51. IPF, 2017a. Globalna inicijativa za fiskalnu transparentnost: Načela sudjelovanja javnosti u fiskalnoj politici. Newsletter (110). doi: 10.3326/nlh.2017.110

52. IPF, 2017b. Globalna inicijativa za fiskalnu transparentnost: Načela visoke razine fiskalne transparentnosti, sudjelovanja i odgovornosti. Newsletter (109). doi: 10.3326/nlh.2017.109

53. Irwin, T. C., 2013. Shining a Light on the Mysteries of State: The Origins of Fiscal Transparency in Western Europe. IMF Working Paper, WP 13/219. Washington: International Monetary Fund.

54. Jurković, P., 1989. Fiskalna politika u ekonomskoj teoriji i praksi. Zagreb: Informator.

55. Jurković, P., 2002. Javne financije. Zagreb: Masmedia.

56. Justice, J. B. and Dülger, C., 2009. Fiscal transparency and authentic citizen participation in public budgeting: The role of third-party intermediation. Journal of public budgeting, accounting \& financial management, 21(2), pp. 254288.

57. Kopits, G. and Craig, J., 1998. Transparency in Government Operations. IMF Occasional Paper, No. 158. doi: 10.5089/9781557756978.084.

58. Ministry of Finance of the RC, 2017. Vodiči za građane. Zagreb: Ministry of Finance of the Republic of Croatia. 
59. Miošić, N., Bronić, M. and Škrabalo, M., 2013. Indeks dobrog upravljanja u Hrvatskoj 2012. Zagreb: GONG.

60. Musa, A., 2014. Transparentnost - zašto i kako? in: A. Musa [ed.]. 5. forum za javnu upravu: Transparentnost u javnom upravljanju. Zagreb: Friedrich Ebert Stiftung, Institute of Public Administration, pp. 7-26.

61. Musa, A., Bebić, D. and Đurman, P., 2015. Transparency and Openness in Local Governance: A Case of Croatian Cities. Hrvatska i komparativna javna uprava, 15(2), pp. 415-450.

62. OECD, 2015. Recommendation of the Council on Budgetary Governance. Paris: OECD.

63. Ott, K. [et al.], 2016. Budget transparency in Croatian counties, cities and municipalities (November 2015 - March 2016). Newsletter (107). doi: 10.3326/nle.2016.107

64. Ott, K. and Bronić, M., 2015. Citizen Participation in Fiscal Policy and Budgetary Processes in Croatia. Newsletter (96). doi: 10.3326/nle.2015.96

65. Ott, K. and Bronić, M., 2015a. Public participation in fiscal policy and budget processes in Croatia. Global Initiative on Fiscal Transparency.

66. Partnerstvo za otvorenu vlast, 2017 (Open Government Partnership, 2017). Partnerstvo za otvorenu vlast.

67. Petrie, M., 1999. The IMF Fiscal Transparency Code: A Potentially Powerful New Anti-Corruption Tool. Paper presented at the ninth International AntiCorruption Conference, Durban.

68. Petrie, M., 2011. Defining the Technical Content of Global Norms: Synthesis and Analytic Review. Revised Phase 1 Report for the Advancing Global Norms Working Group. Global Initiative for Fiscal Transparency.

69. Philipps, L. and Stewart, M., 2009. Fiscal Transparency: Global Norms, Domestic Laws, and the Politics of Budgets. Brooklyn Journal of International Law, 34(3), pp. 797-860.

70. Rubin, I. S., 2006. Budgeting in: B. G. Peters and J. Pierre [ed.] Handbook of Public Policy. London: Sage Publications, pp. 139-150.

71. Rules of Procedure of the Fiscal Policy Committee (Poslovnik o radu Povjerenstva za fiskalnu politiku), 2013. Available at: <http://www.sabor.hr/fgs. axd?id=26962>.

72. Rules on the public transparency of the work of Parliament and its working bodies (Pravilnik o javnosti rada Hrvatskoga sabora i radnih tijela), NN 66/05.

73. Struić, G. and Bratić, V., 2017. Sudjelovanje javnosti u zakonodavnom postupku: primjer Odbora za financije i državni proračun Hrvatskoga sabora. Hrvatska i komparativna javna uprava, 17(1), pp. 131-152. Available at: $<$ http://hrcak.srce.hr/178724>.

74. Struić, G., 2017. Uloga i način uređenja javnosti u hrvatskom parlamentarnom pravu od 1947. do 1953. Pravni vjesnik, 33(2), pp. 101-122. doi: 10.25234/ $\mathrm{pv} / 5111$. 
75. The Constitution of the Republic of Croatia (Ustav Republike Hrvatske), NN 56/90, 135/97, 8/98, 113/00, 124/00, 28/01, 41/01, 55/01, 76/10, 85/10, 5/14.

76. The Treasury of the New Zealand, 1996. Putting It Together: An Explanatory Guide to the New Zealand Public Sector Financial Management System.

77. United Nations, General Assembly, 2012. Resolution 67/218. Promoting transparency, participation and accountability in fiscal policies.

78. von Hagen, J. and Harden, I., 1996. Budget Processes and Commitment to Fiscal Discipline. IMF Working Paper, No. 78. Washington: International Monetary Fund. 